\title{
Teaching EST in Algeria: Training or Retraining Language Teachers?
}

\author{
Nawal Mebitil, Assistant Professor \\ Department of English Language and Literature, University of Mascara, Faculty of \\ Letters and Languages, Mascara, Algeria \\ Email: mebitilnawal@hotmail.fr
}

Doi:10.5901/mjss.2014.v5n20p2381

\begin{abstract}
In this new millennium, learning English to fulfil communicative purposes becomes a worldwide concern, and Algeria is one of the interesting nations in developing the status of English regarded as a key to scientific and technological development. To meet such a challenge, the educational authority in Algeria implements the use of English mainly at all tertiary-level institutions. ESP courses are provided in different departments to meet learners' specific objectives both academic and occupational. In this respect, teaching English for Specific Purposes (ESP) at the university level seems to have its own challenges and requirements in Algeria. This is, particularly, on the part of the language teacher and to ensure learners' success, teachers' qualifications, attitudes, and attributes have to be taken into consideration along side with the learners' needs and desires. In this line of thought, our General English teachers often express their inadequacy for such positions; this may occur because of their fear of being unable to cater for their learners' specific needs. As a result, being unprepared for teaching ESP, language teachers often find themselves obliged to rely on their own experience to teach those classes, as well as, to create their own teaching materials with respect to their students' discipline and needs, too. Therefore, the main aim of the current paper is to present, discuss and reflect upon the actual situation of the language teachers who have been trained in linguistics, phonetics, civilization,...etc, and who are recruited to teach EST at the physics department within the faculty of Exact Sciences of Tlemcen University, and to search for the possible ways to increase the competence and confidence of those EST practitioners through a moderate call towards retraining them in other areas of interests.
\end{abstract}

Keywords: ESP, EST, language teachers, qualifications, situation, training.

\section{Introduction}

In this new and unique millennium where the world is struggling to interconnect mainly under Globalization, a wide variety of changes are, chiefly, taking place. In this sense, our first concern as individuals in that large-scale context is not only to outline those impacts of this process upon the world political, economic and commercial systems, but also to go beyond to mark out its immediate effects on a set of countries which are seeking change, essentially, for a better future. In this line of thought, Algeria, the nation which is looking for an internal recovery and international comeback has and still is endeavouring to reform all its systems including the educational one.

\section{Problematic}

As an interesting part of those Algerian reforms is the adoption of different strategies and systems in a hope to achieve a better teaching/learning process at all levels of education. At the tertiary level, our ministry of Higher Education and Scientific Research has called for the implementation of the 'LMD' system as a new-fangled policy for a change, besides the ESP courses.

In ESP context, language teachers who are considered to be responsible for the teaching and learning process, supposed to deliver suitable content and valuable guidance for their learners, they themselves prove to encounter serious difficulties preventing them to adequately function for the required purposes as so much focus is given to the learner and almost neglecting the teachers' professional needs to cope with the actual requirements. In this vein, our first concern as researchers is to try to shed some fresh light on our higher educational settings while implementing ESP courses, to reflect upon a set of facts in the eyes of both key parameters notably; our learners and their teachers, to outline their current situations and future perspectives is believed to be of worthy significance.

Hence, our enquiry would be mainly articulated in the following way: What are the main difficulties our teacher, besides, their learners are fundamentally faced to? What are their major prospects? Can someone speak about a better 
professionalization of the teaching/learning process without reconsidering our ESP lecturers' preparations?

\section{Context Description}

Algeria, as the rest of the globe, endeavours to implement and therefore, develop the use of English to insure better communication, as well as easy access to knowledge for students, workers, researchers, etc. At the tertiary level, English is introduced in different curricula at different departments nationwide, either as a main subject at the English department and by which students are required to attend the following modules: Literature, Civilization, Linguistics, Phonetics, Oral Expression, Written Expression, TEFL and so forth; or simply as an additional but 'compulsory' module. At this department, i.e., English language and Literature Department, the majority of teachers who are in charge of these courses are full time teachers and who hold either Magister or PhD degree. Part time teachers can also teach and they often hold a License in English and are either first year or second year Magister students.

As mentioned above, apart from the English Department, English is also introduced in other departments and it holds the status of an additional module but 'compulsory'. Students who belong to one of the following specialties: Mathematics, Physics, Chemistry, Sciences, Engineering, Economics, Political Sciences, etc, are required to follow ESP courses, depending on their area of research and their needs, as well. Hence, different ESP courses are provided nationwide under different labels. The most common ones are: EST 'English for Science and Technology', EBE 'English for Business and Economics', and ESS 'English for Social Sciences'. As a result, English as a component is studied alongside their current modules.

The vast majority of these teachers are part time teachers who are engaged in other situations and who have other duties, besides their permanent jobs such as teaching at other departments; the English department for instance, or teaching at other levels; secondary or middle school.

\section{Situation Analysis}

The need to learn English is, basically, associated with the need to form language teachers who are able to teach English either for General or Specific Purposes. At Aboubekr Belkaid University, ALGERIA the situation under investigation, where a rapid growth and expansion has gradually taken place these recent years, English is taught in a separate department within the Foreign Languages Faculty as a main subject. At this department and after accomplishing either four years (in the classical system) or three years (in the LMD system) students are rewarded with a BA degree in English, and by which they are able to work as English teachers.

Hence, once they get a position as teachers they hold the status of EFL teachers; this is mainly due to the fact that during their training, they had no ESP teaching methodology. Therefore, one may say that an ESP teacher is originally a General English teacher who is recruited to teach ESP courses, and by which he can apply for positions in different departments including the English one. At this level, it should be stressed on the fact that those teachers are facing a lot of contextual hindrances.

To move a step further, I deeply believe in the fact that, language teachers who are asked to provide and run ESP courses do not have any special training or instruction that may help them better cope with the requirements of the particular situation they are involved in before starting their careers as ESP teachers. As a result, they may encounter a difficulty of being not well prepared or as has been stated by Hutchinson and Waters (1987:157): " ... a new environment for which they have generally been ill-prepared."

In this regard, it is generally presumed that the common two features of ESP teaching are notably; time allotted for English teaching which is only a period of one hour and half per week; the second common feature is the nature of the job; language teachers, in almost cases, are, only, part-time practitioners.

To put it differently, ESP courses are generally planned as the last course of the day, or even the last course of the week. This fact may have negative impact on learners' attendance, motivation and achievements. The insufficient time may affect, also, the content of the course since the ESP teacher needs to reach a set of goals he/she planned before starting his/her course. As a result he/she is required "to teach them only the bits of English they need." (Bastrkmen 2006:18)

Apart from the time allocation, teachers in ESP situations often claim about the group' size, i.e., the number of students in each class; He/ she is often obliged to deal with large classes with mixed abilities and of heterogeneous needs. Moreover, ESP courses are considered as less important and of a secondary value and position. This fact is proven by a series of reasons:

First of all, no attention was given to ESP; since curriculum developers who are most of the time the language 
teachers in charge of these courses did not provide clear courses' objectives, content, as well as a clear methodology. As a result, teachers are free to decide about their courses and they teach whatever they may judge useful and appropriate for their students.

A grammar-translation method is often used in ESP classes as a result no communicative activities are used; the focus is on activities and tasks of grammar nature. Though in some cases, teachers may conduct some discussions which will be of general interest under the corroboration of improving students' communicative needs.

Because of learners' background in English which is in most cases a poor one and due to the fact that the majority of these lessons do not match learners' needs, a negative attitude from the learners' part could appear either by talking to each other and neglecting the teacher's presence or simply by leaving the course.

As a reaction to this situation, the teacher who is already stressed, who has received no special training as an ESP teacher, who has no orientation and who receives no help from his colleagues, he often leaves his work for the reasons cited before, in addition to the nature of the job which is of a part-time nature and which is not motivating financially.

\section{Learners' Prospects in the New Millennium within our Higher Educational Contexts}

In ESP teaching/learning situation, it is of paramount importance to have a careful and deep look at the difficulties, besides the prospects of our learners since needs analysis is regarded as the foundation stone that may help ESP practitioners to respond correctly and accurately to those wants, lacks and perspectives, as well.

Depending on both parameters; the learners' answers provided in the questionnaire besides, the teacher's observation process the following difficulties have been outlined on the part of the learners:

$\checkmark$ Lack of motivation; English is not important for them;

$\checkmark$ Low level of language proficiency. Hence, they encounter a set of problems at different levels: Grammar, vocabulary, pronunciation, sentence structure and so forth;

$\checkmark$ Lack of appropriate terminology for their fields of study, i.e., physics.

Based on the outlined difficulties, the learners have suggested translation as a main remedy for those issues. To include translation for them may help them express better their ideas, transfer the amount of information they have from their L1 to L2. They have, in fact, mentioned translation from Arabic, or French to English and vice versa to learn more specialized terms.

To go a step further and apart from including specialized translation in our contexts, it should be revealed that ESP apprentices are already adult learners aiming at achieving a particular target namely; improving their level of English language proficiency which may facilitate for them, later on, different tasks including publication of papers in the target language and taking part in seminars and workshops, etc. In this case, it could be mentioned that, our learners are still claiming about the content provided for them in ESP courses as this latter does not match their real needs. At this level, I may dare to say that there is a gap between the knowledge afforded and that expected in such context, this may be due to the fact that those language teachers responsible for running such type of courses have no previous specialized training in the area they are currently taking part in.

Students, in this case, have called for a thorough consideration of their wants, lacks and outlooks including fundamentally the following points;

* To design courses based on their real needs;

* To take part in the process of determining the content of the course;

* To provide real-life tasks which may help them function adequately while involved in authentic situations;

* To afford a wide range of tasks aiming at enhancing their level of English language proficiency besides, their motivation, too.

* In addition to the already mentioned key-element which aims, basically, at including specialized translation within their context.

As an ESP practitioner, I may say that including specialised translation in our scientific context aiming at improving our learners' level of English language proficiency is considered to be of creditable importance. In EST milieu, translation is no more seen as a separate trend but as an integrated activity, and skill aiming at facilitating the way for our learners to better grasp the content of their courses and, later on, function adequately in their target situations. Specialised translation, in this case, is, therefore, seen as a vocabulary builder tool, a way to mediate culture and an instrument which may help our learners expand their knowledge, evaluate and assess their performance, too. 


\section{Reflections on Teachers' Preparations in the Light of their Qualifications}

Based on a personal experience while investigating the area of ESP at the level of Aboubekr Belkaid University, Tlemcen, ALGERIA, it has been noticed that the ESP teacher who constitutes a key-parameter in the teaching/learning process has been neglected. This may be considered as the main reason for such a failure in this process, regardless learner's needs, wants and lacks, and their levels of proficiency, as well.

As the central issue of the current work revolves, therefore, around the ESP context with all the particularities that may underlie, it can be stated that improving the ESP teaching/learning practice, could not be reached unless a careful examination of teachers' preparations, roles and qualifications is, almost, provided and, deeply, discussed. In other words, and derived from the results of the already conducted needs analysis, our language teachers need, fundamentally, to be retrained to respond positively to the requirements of their target situations besides, their learners' expectations.

As a first stone in providing, more or less, an accurate evaluation which may help us later on suggest a set of remedies, it can be stated that training as a process which is 'the formal preparation of prospective teachers' may entail two phases, namely pre-service and in-service training courses. Taking the ESP teachers as a case study, it can be assumed that, an ESP practitioner needs to be trained before being involved in the ESP teaching situation first as a language teacher. Later on, while he/she is involved in such a situation he/she may need to undergo an in-service training which should suit his/her needs and the field he/she is involved in.

Believing in the fact that, the main aim which stands behind undertaking a pre-service preparation is "to help them [future teachers] enhance and improve language abilities, pedagogical skills, and cultural knowledge." (Song, et al, 2011: 100) to function adequately as a teacher, an ESP practitioner should, first of all, undergo a pre-service general training phase by which he is required to attend the following lectures, including a variety of sciences which revolve around the Teaching of English as a Foreign Language (TEFL) as it is its case, here, in Algeria. In this phase, a prospective ESP teacher should be well equipped with a sound training which includes: phonetics; linguistics; psychology; pedagogy; methodology and so forth. Furthermore, he or she must undertake a 'specialized training' where other areas such as needs analysis; syllabus design; materials production; specialized language 'terminology', must be, carefully, addressed. At last but not least, practice is almost needed.

Joining this idea, and as a main part of their preparations, language teachers are supposed to acquire a set of qualifications which are considered to be a prerequisite. These latter will help them function adequately in any teaching situation. In this regard, the ESP teachers; like the general language teachers, need first to acquire three types of competences, notably Language Competence; Pedagogic Competence and Language Awareness. In addition to another element which is related to the specialised knowledge depending on the learners' area of specialism. The following diagram is an attempt at summarizing this view:

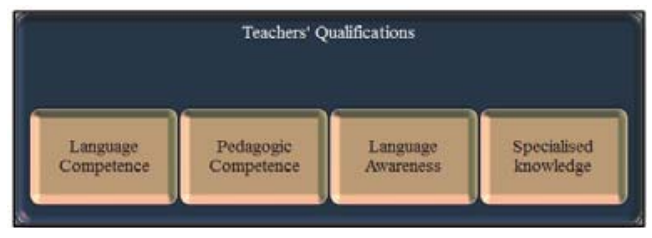

Fig. 1. Teachers' Qualifications (Adapted from Thomas 1993)

In other words, if a teacher lacks one of these competences, he or she may not be able to function appropriately as a language teacher. Accordingly, these four competences are believed to be of vital value for those instructors. Joining this idea, and though our Algerian language teachers may be well equipped with the three first competences notably, language competence and awareness, pedagogic competence, they, in most of the cases, lack the fourth element which is specialised knowledge. This latter is believed to be of worthy significance for them to facilitate the task of teaching and hence, functioning adequately in their target milieu.

According to Thomas (1993), Language Competence is a pre-requisite for the language teacher. Taking into consideration that an Algerian ESP teacher is not a native speaker of English, this does not imply to have a native-like competence. His role, in contrast, is to help learners to function effectively in their target settings.

On the other hand, pedagogic competence implies the ability to teach effectively. This is commonly due to the fact that, one may have a good command of a language but this does not mean that he/she is a good teacher. (Richlin, 2006) 
To achieve this end, the teacher should keep in touch with the current research works about teaching/learning process. Attending conferences and workshops may also constitute a great help for the instructor.

One of the teachers' duties is the ability to supervise both processes namely, language use and learning in the classroom. This can be achieved through conscious reflection on language which could be accomplished by going beyond the ability to only use the language. In this regard, language awareness is a key-parameter in ESP teacher training because of the fact that "the language content of the ESP courses usually differs from that presented on general language courses". (Lomax et al 2002: 131)

In addition to those competences cited above, I have felt the need to introduce another element to better cope with the requirements of an ESP teaching situation. This latter is theoretically known as 'a specialized knowledge'. In this line of thought, ESP is often defined as the teaching of English for a "clearly utilitarian purpose" (Mackay et al, 1978), depending on the learners' field of study; current; and future situation and needs, as well. Hence, an ESP teacher is often faced with adult learners who are supposed to have specialised knowledge of the field and scope of research, and who seek to learn the kind of English which is believed to be encountered in their educational context. As a consequence, the role of the ESP teacher is considered to be about helping students to communicate effectively in the target language while using their knowledge related to the field they are, fully, taking part in. To achieve this purpose, a certain level of knowledge of the learners' area of study is required. However, it is to be stated at this point that the primary concern of those teachers is to teach language and not the speciality. This idea has been clearly articulated by Bojovic (2007:493) "ESP teachers are not specialists in the field, but in teaching English, their subject is English for the profession but not the profession in English".

To move further in evaluating and, hence, assessing the effectiveness of our teachers' preparations, it can be proclaimed that any prospective practitioners may feel inadequate if they seek to rely on what they have learnt in theory, they, then, need to find a way to practise what they have acquired in the theoretical phase. This latter can be achieved through observing other teachers, and later on, they may be asked to run the course under their trainers' monitoring. Trainers' supervision may constitute a great help for a prospective teacher who does not only need supervision but a feedback on their performance, as well.

As it has been discussed above, pre-service teacher training is of paramount importance for prospective teachers. On the other hand, and for those who are already involved in ESP teaching situations, in-service teacher training may constitute a great help for them. This can be achieved through attending workshops and seminars by which they seek to cater for a better professional development. In the same line of thought Savas (2009:402) writes:

Language teachers and prospective language teachers can attend professional development workshops to let themselves acquire a second field of expertise, such as medicine, engineering or law.

While taking part in such training, ESP teachers may benefit a lot; "new teachers learn from veterans. They become oriented more quickly and effectively." Buckley (2000:12)

Believing in the fact that, ESP is still in its infancy here in Algeria and our Algerian ESP practitioners lack expertise in their teaching field and have no enough preparation as they did not undergo an adequate training for the field they are either already involved in or aiming to take part in, and lack a specialised knowledge to perform those outlined tasks, in this case, teaching EST groups is considered to be a difficult assignment or even their nightmare. Retraining them, in this case, in a wide range of areas will facilitate not only the task of teaching for them and but also help them better respond to their learners' needs.

\section{Conclusion}

Ultimately, to provide a set of hopefully useful recommendations and suggestions is mainly done as a path toward filling the existing gap between the requirements of the actual situation and the needs of those key-parameters namely our teachers and their learners for their own benefits. Nevertheless these pedagogical, as well as administrative reforms remain only theoretical unless a radical change in addition to serious actions put into practice by those who are considered as the decision makers first at the university level then to a higher level by the ministry itself.

This could be done mainly for the sake of maintaining balance between the requirements of different situation; being academic or professional and the increasingly developed demands of technology, economy and sciences through preparing teachers whose main aim is to promote the ESP teaching situation and who are absolutely aware of the requirements of their different teaching situations, who have knowledge of the main principles ESP is based on, and who are ready to accept change by adopting positive attitude toward the fields they are teaching, and before all who can better articulate and respond to their learners' actual needs and future prospects. 


\section{References}

Basturkmen, Helen. (2006). Ideas and Options in English for Specific Purposes. Mahwah, New Jersey: Lawrence Erlbaum Associates.

Bojovic, Milevica. (2007). "Teaching Foreign Language for Specific Purposes: Teacher Development". < http://www.pef.uni-lj.si/atee/978961-6637-06-0/487-493.pdf> February 2010.

Brown, G \& Howard, R. ed. (Eds.) (1997). Teachers Education for Languages for Specific Purposes. UK: Multilingual Matters, Ltd.

Buckley, F, J (2000). Team Teaching: What, Why and How? California: Sage Publications, Inc.

Dudley-Evans, T \& St John, M. (1998). Developments in English for Specific Purposes: A Multi-Disciplinary Approach. Cambridge: Cambridge University Press.

Hutchinson, Tom \& Waters, Alan. (1987) English for Specific Purposes: A Learning Centred Approach. Cambridge: Cambridge University Press.

Lomax, T, H, R \& Ferguson, G. (Eds.) (2002). Language in Language Teacher Education. USA: John Benjamins B.V.

Mackay, R \& Mountford, A. (1978). English for Specific Purposes: A Case Study Approach. London: Longman.

Mebitil, Nawal. (2011). An Exploration of the Main Difficulties, Challenges and Requirements of the ESP Teaching Situation in Algeria: The Case of ESP Teachers at Abou-Bekr Belkaid University, Tlemcen. (Unpublished Magister Thesis). Tlemcen University

-- (2011b) "Teaching ESP in Algeria: Requirements and Challenges". Revue_Des Lettres et des Langues. Numéro $18,2011$. ISNN 1112-3494.

Richlin, L. (2006). Blueprint for Learning: Constructing College Courses to Facilitate, Assess, and Document Learning. Virginia: Publishing Stylus, LLC.

Robinson, Pauline. (1991). ESP Today: A Practitioner's Guide. New York: Prentice Hall.

Savas, Bekir. (2009). "Role of Functional Academic Literacy in ESP Teaching: ESP Teacher Training in Turkey for sustainable Development". Journal of International Social Research. <http://www.sosyalarastirmalar.com/cilt2/sayi9pdf/savas_bekir.pdf>. February 2010

Song, X. \& Cheng, L. (2011). "Investigating primary English immersion teachers in China: background, instructional contexts, professional development, and perceptions". Asia-Pacific Journal of Teacher Education, 39:2, 97-112

Swales, John. (1985). Writing Scientific English: A Textbook of English as a Foreign Language for Students of Physical and Engineering Sciences. USA: Thomas Nelson and Sons.

Thomas, A. (1993). "Future Perspective on ESP in the Maghreb: Languages, Teacher Training and Management." In the $1^{\text {st }}$ Maghreb Conference; the British Council.

Zughoul, M, R. (2003). "Globalization and EFL/ESL Pedagogy in the Arab World." Journal of Language and Learning Vol. $1 \mathrm{~N}^{\circ} 2: 106-$ 138. 